\title{
Pandemic, Lender Risk and Borrower Bargaining Power
}

\author{
Taofik Hidajat \\ Management Study Program \\ School of Economics and Business (STIE) of Bank BPD Jateng \\ Semarang, Indonesia \\ inidotcom@yahoo.com
}

\begin{abstract}
Risk in peer to peer lending has an upward trend. Uncertain economic conditions make it difficult for borrowers to repay loans because lenders through a free platform determine high loan interest. However, the borrower has no power and choice. This paper examines peer to peer lending conditions and potential violations in setting loan interest rates. The research method used is descriptive research using data from several sources. The results of this study are recommendations to minimize the risk of borrowers and lenders.
\end{abstract}

Keywords: peer to peer lending, financial technology, lender risk, pandemic

\section{INTRODUCTION}

Indonesia's population is categorized into the banked (23\%), underbanked (26\%) and unbanked (51\%) groups [1]. Underbanked and unbanked are groups with low financial inclusion or are not served by financial services.

On the one hand, banks will only provide access to bankable groups with a credit history by performing credit scoring. Thus, groups without a credit record will not have access to loans because no data is available for scoring [2]. These underserved groups will then seek other financial access, such as peer-to-peer (P2P) lending [3].

The absence of information on prospective borrowers in $\mathrm{P} 2 \mathrm{P}$ lending makes this institution's credit risk significant. What is more, P2P lending has information asymmetry [4]. Even though the $\mathrm{P} 2 \mathrm{P}$ lending platform only acts as an intermediary between the borrower of funds and the owner of funds, to reduce this risk, the platform sets high loan interest rates.

In general, P2P lending uses internal credit scoring to assess the feasibility and determine loan interest. Several machine learning methods are widely used to improve credit scoring, such as decision trees, AdaBoost, support vector machines [5], neural networks [6], and k-nearest neighbours [7]. The advantages of machine learning include being able to ignore assumptions in logistic regression and produce better classifications [2] [8].

Some uses of machine learning for credit scoring include the use of Random Forest, AdaBoost, and LightGBM to predict the chance of default in peer-to-peer lending using social network information in China [2], random forest to assess the effectiveness of credit union lending processes in Brazil [8], Naive Bayesian Model, Logistic Regression
Analysis, Random Forest, Decision Tree, and K-Nearest Neighbor Classifier for bank loans in China [9].

This technology allows the P2P Lending platform to assess the borrower's risk and use it as a benchmark for setting loan interest. Interest expense refers to the level of risk that results from the credit scoring process. When a borrower applies for a loan, the P2P platform will analyze data, documents and other information. The results of this analysis produce a loan grade as a determinant of the level and interest costs that must be paid by the borrower.

The borrower has no choice and bargaining power other than accepting the unilateral decision. There are no regulations governing loan interest rates. Business actors and fintech associations (Indonesian Joint Funding Fintech Association) set their loan interest rates. From this, there is a potential for violations in setting loan interest rates. At the same time, consumer law guarantees the consumer's right to choose.

To attract lenders, P2P lending offers high-interest rates. The high interest in $\mathrm{P} 2 \mathrm{P}$ lending is due to unsecured loans, so the risk of lenders is also high. Even so, P2P lending platforms may not charge interest because the interest income is returned to the lender. P2P lenders earn money from service fees. Currently, the loan interest is limited to a maximum of $0.8 \%$ per day; the maximum accumulated penalty is $100 \%$ of the principal.

On this basis, this paper examines the development of $\mathrm{P} 2 \mathrm{P}$ lending in Indonesia and the potential for violations in determining loan interest. This study needs to be done because this industry is growing quite rapidly. As of September 2020, there are $156 \mathrm{P} 2 \mathrm{P}$ companies registered and licensed by the Financial Services Authority (OJK) [10]. Apart from legal ones, the number of illegal P2P P2P, especially from China is also large. This fact is not strange because China has the most P2P lending in the world [11].

Ignoring P2P lending's presence could spark problems in the future. Consumer protection in the financial services sector began to receive attention after the global financial crisis in 2008. This crisis proved that there was a massive impact between financial system stability and consumer protection. P2P lending platforms are also not banking, but their activities are like banking activities, so the regulations should also be different. The certainty of this legal relationship is necessary so that $\mathrm{P} 2 \mathrm{P}$ lending activities do not become shadow banking.

This study uses secondary data. The data source comes from regulations and $\mathrm{P} 2 \mathrm{P}$ lending reports, especially from 
the Financial Services Authority (OJK). The data and information were analyzed using descriptive statistics.

\section{DISCUSSION}

\section{A. Pandemic and P2P Lending}

The P2P lending industry has begun to develop and is known to the people of Indonesia since 2016. This service has received many responses from small and medium enterprises and individuals who do not have access to financial institutions, especially banks. The fast loan process and easy requirements make $\mathrm{P} 2 \mathrm{P}$ lending the choice of these individuals and small businesses. What is more, small and medium enterprises need around IDR 1,600 trillion of funds each year, but banks are only able to channel IDR 600 trillion. P2P lending has enormous potential to grow due to this gap.

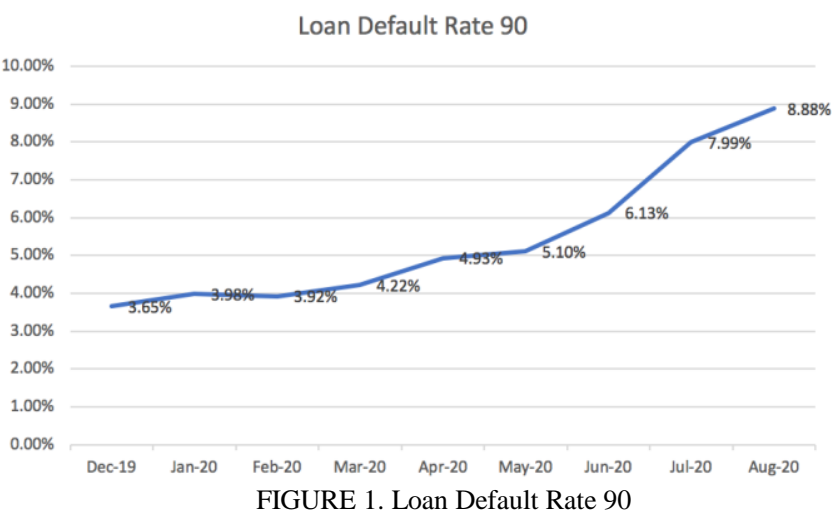

Source: [1]

This statistic is consistent with the loan success rate for 90 days (LSR-90), which continues to decline. Since the Covid pandemic (December 2019), the LSR 90 fell from $96.35 \%$ to $91.12 \%$ (August 2020). This fact shows that there has been a decline in the quality of payments which has led to an increase in non-performing loans. The higher the loan default rate, the lower the loan success rate.

However, there is an interesting fact that the number of investors has increased during the pandemic. During a pandemic, many people stay home and access the internet. They are looking for business and investment opportunities to earn money, including investment through P2P lending.

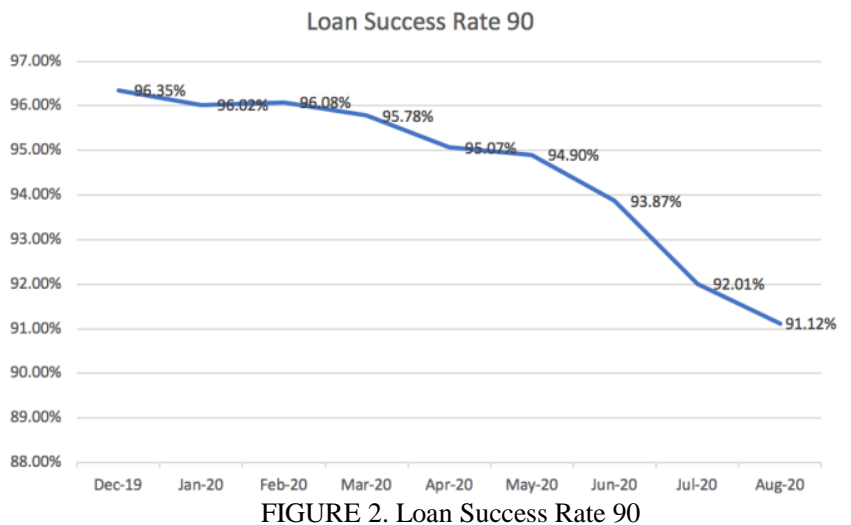

Source: [1]

Uncertain economic conditions due to the pandemic have made people lose income. Many people do not have permanent jobs or work in the informal sector. Moreover, the characteristics of the majority of borrowers on P2P lending platforms are underbanked and unbanked, who do not have a regular income. During a pandemic, many businesses lose money, and workers lose their jobs. The Ministry of Manpower reported the pandemic affected a minimum of 3.05 million workers.

The pandemic makes it difficult for many people to make ends meet, including to pay debts. Defaulting on debt can have a systemic impact in the future. The negative impact is more significant if the borrower is a household because debt affects the vulnerability of the household sector [2]. The greater the debt, the greater the vulnerability of the household [3]. There is a long-term relationship between the macroeconomy and households [4]. Households are owners and borrowers of financial assets that have links to other financial systems so that they can have an impact on the economy at large. Household consumption of debt affects economic system stability and opens up financial crises [5]. The sub-prime mortgage scandal is evidence that credit risk in the household sector has an impact on the economy.

This condition can get worse because of the low level of public financial literacy [6]. Research shows that financial illiteracy and debt literacy can make a person more deeply in debt [7] [8].

\section{B.Determination of Interest and Potential Violations}

Credit score model was introduced by Durand in 1941. Since the mid-20th century, credit score has become a benchmark in the financial industry and has continued to develop until now. In the financial industry, credit scoring is widely used to measure credit risk [9].

Initially, the most widely used technique was logistic regression. Currently, credit scoring has developed by utilizing artificial intelligence [10] such as machine learning and producing a more accurate and efficient model [11] [9] [12]. Recently, P2P lending platforms have used big data technology for credit scoring [13]. 
Machine learning is an artificial intelligence application that uses statistical techniques to generate models from a set of data. In the previous stage, computers were allowed to "learn" from several data using algorithms (machine learning algorithms) to produce the model. Through artificial intelligence, credit scoring will immediately change according to the condition of the customer profile.

How can potential P2P lending violations against customers occur? According to the regulations (POJK $77 / 2016)$, P2P is a loan and borrowing service directly between lenders and borrowers based on information technology. The regulation regulates the maximum limit for providing loan funds to borrowers but does not regulate loan interest limits to borrowers. This regulation also aims to protect consumers against data security, funds, prevention of money laundering, terrorism financing, maintaining financial system stability while protecting the managers of P2P lending companies.

In this regulation, the regulator $(\mathrm{OJK})$ does not regulate the determination of the interest rate. The interest rate is determined by the $\mathrm{P} 2 \mathrm{P}$ lending platform based on the valuation and cost of funds. The fintech association also plays a role in determining these interest rates. This authority to determine interest rates leaves the borrower with no different power. The borrower is the party that must agree to this agreement.

Supposedly, the OJK should not only focus on the development of the fintech industry but also take policies in determining interest rates on P2P lending. Referring to Law Number 21 of 2011 concerning the Financial Services Authority, this institution has the function, task and authority of regulating, supervising, examining and investigating. Increased use of digital services is good news but will backfire if it is not supported by regulations [14].

Legal protection for P2P lending borrowers must be in the form of regulations that provide legal certainty and protection. However, this also needs to be studied more deeply because $\mathrm{P} 2 \mathrm{P}$ lending is not a banking institution that carries out an intermediation function. In the banking system, the legal relationship between a depositing customer and a bank is based on an agreement between the two. In $\mathrm{P} 2 \mathrm{P}$ lending, the relationship between lenders and $\mathrm{P} 2 \mathrm{P}$ lending providers should not be a fund deposit relationship but a legal relationship arising from the power of attorney agreement. On the other hand, the borrower should have a legal relationship with the lender, not with the P2P lending manager. P2P lending organizers receive power from the lender to enter into a money loan agreement with the borrower [15].

\section{CONCLUSION}

Loan success rates in P2P lending have decreased, and default rates have also increased. The Covid pandemic has made it difficult for people to repay loans. This expense increases because the borrower has to pay high interest.
Regulators should not only focus on developing the financial technology industry but also provide policies in determining loan interest rates. A clear legal relationship will facilitate the implementation of the rights and obligations of each party involved in P2P lending. If not, then let the industry regulate itself (self-regulated).

\section{REFERENCES}

[1] Otoritas Jasa Keuangan, "Perkembangan Fintech Lending September 2020,” Jakarta, 2020.

[2] Ardhienus, "Mengukur Kerentanan Sektor Rumah Tangga," 2018. https://id.beritasatu.com/home/mengukur-kerentanansektor-rumah-tangga/173142.

[3] A. L. Andersen, C. Duus, and T. L. Jensen, "Household debt and spending during the financial crisis: Evidence from Danish micro data," Eur. Econ. Rev., vol. 89, pp. 96-115, 2016.

[4] C. Meniago, J. Mukuddem-Petersen, M. A. Petersen, and I. P. Mongale, "What causes household debt to increase in South Africa?," Econ. Model., vol. 33, pp. 482-492, 2013, doi: https://doi.org/10.1016/j.econmod.2013.04.028.

[5] A. Cardaci, "Inequality, household debt and financial instability: An agent-based perspective," J. Econ. Behav. Organ., vol. 149, pp. 434-458, 2018, doi: https://doi.org/10.1016/j.jebo.2018.01.010.

[6] T. Hidajat, Literasi Keuangan. STIE Bank BPD Jateng, 2015.

[7] A. Lusardi and P. Tufano, "Debt literacy, financial experiences, and overindebtedness," J. Pension Econ. Financ., vol. 14, no. 4, pp. 332-368, 2015.

[8] J. Pelletier, "2017 National Report Card on State Efforts to Improve Financial Literacy in High Schools,” 2017.

[9] de P. D. A. Vasconcellos, A. Rinaldo, A. Fabio, and M. A. M. A. Fonseca, "Estimating credit and profit scoring of a Brazilian credit union with logistic regression and machine-learning techniques," RAUSP Manag. J., vol. 54, no. 3, pp. 321-336, Jan. 2019, doi: 10.1108/RAUSP-03-2018-0003.

[10] L. C. Thomas, "A survey of credit and behavioural scoring: forecasting financial risk of lending to consumers," Int. J. Forecast., vol. 16, no. 2, pp. 149-172, 2000.

[11] O. Ceylan and Ö. Elif, "A review of credit scoring research in the age of Big Data," J. Financ. Regul. Compliance, vol. 26, no. 3, pp. 382-405, Jan. 2018, doi: 10.1108/JFRC-06-2017-0054.

[12] X. Dastile, T. Celik, and M. Potsane, "Statistical and machine learning models in credit scoring: A systematic literature survey," Appl. Soft Comput., vol. 91, p. 106263, 2020, doi: https://doi.org/10.1016/j.asoc.2020.106263.

[13] M. Campbell-Verduyn, M. Goguen, and T. Porter, "Big Data and algorithmic governance: the case of financial practices," New Polit. Econ., vol. 22, no. 2, pp. 219-236, 2017.

[14] I. Agur, S. M. Peria, and C. Rochon, "Digital financial services and the pandemic: Opportunities and risks for emerging and developing economies," Int. Monet. Fund Spec. Ser. COVID-19, Trans., vol. 1, pp. 1-2, 2020.

[15] R. Hartanto and J. P. Ramli, "Hubungan Hukum Para Pihak dalam Peer to Peer Lending," J. Huk. Ius Quia Iustum, vol. 25, no. 2, pp. 320-338, 2018. 